\title{
Absolute Study of Language Using Softskill Methodology
}

\author{
Rosida Tiurma Manurung ${ }^{1}$ \\ UK Maranatha ${ }^{1}$ \\ rosidatm@gmail.com
}

\author{
Keywords : \\ Language of language, hard \\ skill, soft skill, model soft skill \\ methodology
}

\begin{abstract}
The aim of this paper is to do a research on study of language using soft skill methodology, because the supremacy of language is not solely master on concepts, theory, ideas, and etiquette of language, but the important thing is the supremacy of language that can be used as expansion character and personality. If this happen, people will supreme on language skill with expansion on character and high moral to dig the effectiveness. The need of skills are not technical. With soft skill, ones is able to have the circumstantial sensitivity, high creativity, that is able to look for unthinkable opportunity and gaps by others, conducting new concepts and innovative, and also can fulfill a new demand in society. Based study on soft skill methodology, it is expected to develop intelligence together with expansion character, sensitivity, personality, activity in social interaction, and high moral. The supremacy of language based on hard skill represents the old concepts and is out of date. The supremacy of language with soft skill methodology is absolute. In the discussion above, found the following things. In language learning, each teaching material is given special themes that can provoke soft skills of learners, in language learning in the classroom, there must be an interaction between lecturers and students, it is necessary to design tasks that empower soft skill skills to learners, with the soft skill approach, we can design the rules in the class, in language learning, soft skill approach can also be done in extra curricular and to support language learning with soft skill approach, there are activities that can be used to develop soft skill.
\end{abstract}

\section{INTRODUCTION}

The task of educators is not just teaching, but inspiring humans to thrive completely. Thus, it takes a learning model that can improve the human soul. In language learning is easy to use soft skill approach because soft skill is the soul in every process of learning whether it is the field of engineering and non-engineering. According to the International Commission's report on education for the XXI century of UNESCO in a book entitled Learning The Treasure, identified the four pillars of 
education as follows 4 pillars of education. On each pillar required soft skill LEARN TO KNOW (It means learning to gain knowledge or skills to learn something). LEARN TO DO (Learn to be able to work or work / proficient). LEARN TO BE (This means willing to learn to be a useful person / skill to live). LEARNING TOGETHER (It means learning to live with others).

In the practice of learning, learning resources must be developed in the presence of the above pillars and make the paradigm a lifestyle (life skill). The learning process will run optimally if we succeed in building skills known as cognitive ability, affective ability, and psychomotor ability. As seen from this scheme.

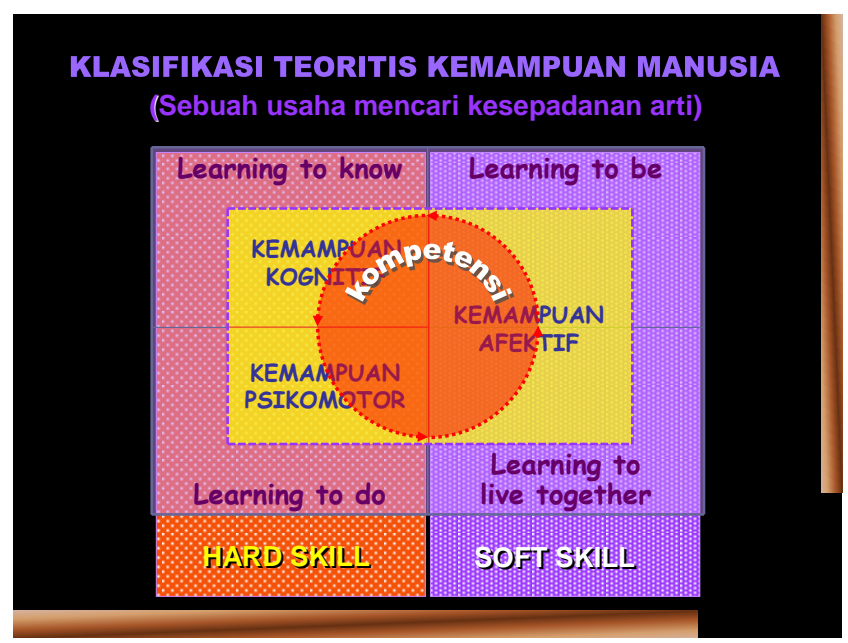

Fig 1. The learning process

Conversely with cognitive ability is a process or product of the mind to achieve knowledge that is a mental activity such as remember, symbolize, categorize, solve problems, create, or expect something. Cognitive ability closely with the development of intellect and brain intelligence functions. Cognitive ability is realized with the effort to learn to know.

Conversely with affective ability is the attitude associated with emotions. Affective ability with regard to interests and attitudes that can be responsible, cooperative, disciplined, committed, confident, honest, rewarded by others, and the ability to control oneself. Affective ability becomes the driving force of students to improve the quality of self. Affective ability is manifested by learning to become and learn to live together.

What is meant by psychomotor skills is the ability associated with the skills of students to utilize the knowledge they have. Thus, the knowledge needed for information in the virtual world that is stored to freeze in the brain, can be implemented to help maximize the ability of students. Psychomotor ability of word range regarding motion, use of muscles when running, jumping, painting, talking, disassembling, or tools. Psychomotor ability manifested by the effort to learn to do. Cognitive and psychomotor abilities produce so-called hard skills, while affective ability produces soft skills.

In the educational strategy, soft skills are needed as a supporter as well as the media to produce a competent learner profile in the theoretical field of science, but also have persistence, professionalism, high creativity, leadership, honesty, and so on. The scheme is shown below. 


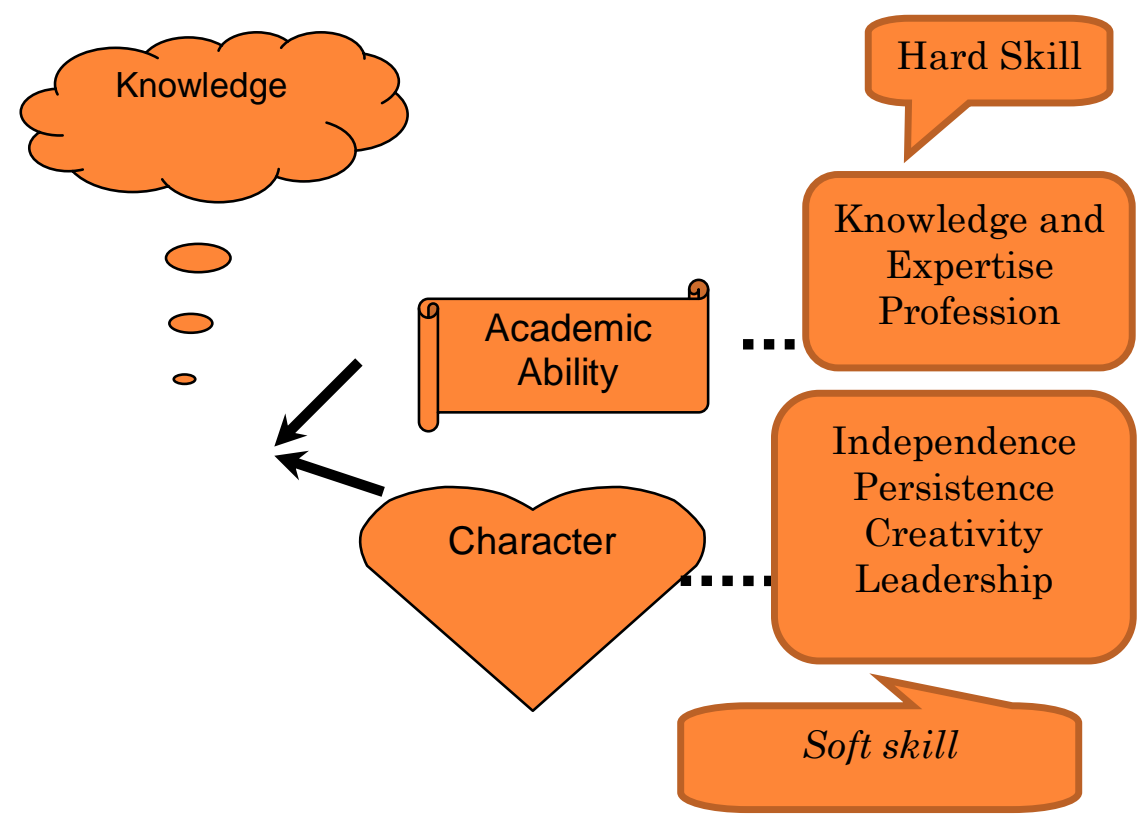

Fig 2. Theoretical field of science

Learning model determines whether or not successful learners understand the teaching materials. In addition, with the right model of learning, the goals and competencies of learning to be achieved can be realized. According to Hamalik (2003), the learning model is an organized combination that includes human elements, materials, facilities, equipment, and procedures that interact to achieve a goal. In the language learning model, the human element consists of learners, teachers / lecturers, and other persons who support the learning process (eg administration, floor attendant, cleanning service, laboratory personnel, or even parking attendants). The so-called materials are teaching materials, reference sources (books, magazines, dictionaries, CDs, DVDs, slides, photos, etc.). Facilities are facilities and infrastructure that support the process of learning, for example, classroom layout, lighting, audio-visual equipment, computer equipment, OHP devices, sound systems, and so on. Procedures are activities undertaken in the learning process, for example, learning strategies, learning approaches, learning schedules, implementation of learning, and so on.

The language learning approach includes the procedures in the learning model. Approach is certainly necessary. How successful language learning can be realized depends on the accuracy of choosing an approach in the process of language learning.

A. Approach in Language Learning

\section{DISCUSSIONS}

Before the process of language learning takes place, we must formulate and determine the learning approach. Here are the benefits of approach in language learning 
1. Approach makes language learning become planned, have purpose, focus, targeted and certain.

2. With the approach, the determination of language learning component is easy to do, the learning steps can be arranged systematically, the development of learning can be optimal, and the learning process more effective.

3. With the approach, potential, and available resources optimized. Exploitation and exploration of each learner in the process of thinking and reasoning can be maximized.

4. With approach, the feedback process can be monitored and feedback assessment can be done. Based on feedback, which components should be improved, adjusted, maintained, or even eliminated.

B. Language Learning Approach with Soft Skill

1. Definition of Hard Skill

Hard skill is the mastery of science, technology and technical skills related to the field of science. Engineers should master the science and engineering of machinery, doctors must be qualified in medicine, and soccer players have the technique of dribbling technique. Each profession is required to have a special hardskill, but softskills cam be a must-have ability in every profession.

2. Definition of Soft Skill

Soft skill is someone's skill in dealing with others (INTERPERSONAL SKILLS) and selfgoverning skills (INTRA-PERSONAL SKILLS) capable of developing maximum performance.

People who have intrapersonal skills have the following characteristics (Gunawan, 2005: 114):

a. able to realize and understand the meaning of the emotions of himself and the emotions of others

b. able to express and channel feelings and thoughts

c. developing a good and true self concept

d. motivated to determine and pursue a life goal

e. setting and living with a value system that is consistent with ethics

f. interested in meaning of life, purpose of life, and its relevance to the current circumstances

g. able to develop sustainable learning ability and always improve themselves

h. able to explore and comprehend the complexity of a person and the human condition in general 
People who have intrapersonal skills will be able to understand themselves, understand others, make plans, imagine things, and solve every problem. People who have interpersonal skills according Gunawan (2005: 118) has the following characteristics:

a. establish and maintain a social relationship

b. able to interact with others

c. recognize and use different ways to connect with others

d. able to influence the opinions or actions of others

e. participate in the efforts of various appropriate roles begin to become followers until they become leaders

f. observing the feelings, behaviors, thoughts, motivations, and lifestyles of other people

g. understand and communicate effectively both in verbal and nonverbal forms

h. develop skills to mediate in a conflict, be able to work with people of diverse backgrounds

i. sensitive to one's feelings, motivations, and mental state

Interpersonal skills enable us to communicate and understand others, understand different states of mind and mood, attitude or temperament, motivation, personality, and be able to form and maintain a relationship. Students who have this ability stand out in group work, can influence their friends, be smart to bring themselves, and love to interact.

C. Absoluteness of Soft Skill Approach in Language Learning

In language learning, soft skills approach is absolutely applied. The following will describe language learning with soft skill approach.

1) In language learning, each teaching material is given special themes that can provoke soft skills of learners. For example, in instructional materials, students should write about environmental issues, industrial waste, water and electricity savings, foster care programs, and so on. Learners can be assigned to make stickers about water saving directly installed near water taps on campus toilets and electric saving stickers that are directly attached near electrical switches across campus all of which use good and proper Indonesian language.

2) In language learning in the classroom, there must be an interaction between lecturers and students. Interaction is mutual action, there is a reciprocal relationship, there is a two-way communication. Interactions are of course dynamic, not static. In language learning, verbal interaction is most prominent and dominant.

3) It is necessary to design tasks that empower soft skill skills to learners. For example, providing group assignments in the form of analysis reports of interviews to small traders selling near the campus. In addition to the students apply the theory of interview techniques and report writing, they are also touched to realize care or concern to the little wong. In addition, the assignment of group discussions by role play, forcing learners to empower their soft skills. With role play, they can be creative in playing the character, synergize with others, train the role, train the sensitivity, and train to actualize themselves. Role play in language learning, for example, plays the role of overseas students studying in big cities who are ridiculed by their friends for using Indonesian language berialek dang diinterferensi by regional language mixing with the Indonesian language. In addition to the achievement of teaching materials that are language interference, as well as role play activities can foster moral values that respect peoples, pluralism, and every person has a uniqueness. Assignment can be done by utilizing computer technology, such as creating creative, innovative, and full of creative and animated point of view when learners present their tasks.

4) With the soft skill approach, we can design the rules in the class. For example, rules should not be cheated, rules should not be late, well-dressed rules, rules on shoes, rules do not activate mobile phones, do not eat or drink in class, pray before and after learning, and other rules that can empower soft skill skills. In language learning, we can apply the rules of "standard, good and correct language use zone" in the class if any of the violations may be fined (eg Rp5000.00 per violation and the result can be donated to foster care program).

5) In language learning, soft skill approach can be done in extra curricular. For example, learners get training into a news presenter, presenter of a sporting event, or a music event presenter. 
Learners can also develop interpersonal skills through theater activities, campus art units, sports, study groups, and research groups.

6) To support language learning with soft skill approach, activities such as English-language debate between departments, presentation of research findings by students in public, poetry reading contest with musicalization, computer technology use in poster making about jargon / political expression which builds and educates the nation, and so on.

7) As a measurable form of language learning to a rotating soft skill approach every parallel class once a week teaches in primary schools where the majority of students are children of weak economic parents. In the UK Maranatha Indonesian Language Course each semester has 35 40 parallel classes. Each class gets an opportunity to visit Anugerah Primary School located in front of the campus, but into narrow alleys and the situation is very alarming. The students are trained to become volunteers / volunteers to help their younger siblings learn good and proper Indonesian, learn to write, and learn to read. The sensitivity of learners to empathize, to feel the condition of concern, to witness firsthand the suffering of life, and to know that in the surrounding it turns out there are communities or groups who are economically disadvantaged ultimately make learners will appreciate life and life. Practice being a volunteer can develop soft skill learners.

No matter how sophisticated the curriculum is structured and formulated, no matter how smart the teacher is, no matter how learning facilities and infrastructure, it will mean nothing if the teacher does not actively contribute to the development of soft skills. As good as any learning material if not accompanied by the planting of honesty values, piety, discipline, obedience, sensitivity, and kindness, vain all the material that has been verbally given in the classroom.

\section{CONCLUSION}

In the discussion above, found the following things. There are is in language learning, each teaching material is given special themes that can provoke soft skills of learners, in language learning in the classroom, there must be an interaction between lecturers and students, it is necessary to design tasks that empower soft skill skills to learners, with the soft skill approach, we can design the rules in the class, in language learning, soft skill approach can also be done in extra curricular, to support language learning with soft skill approach, there are activities that can be used to develop soft skill, teachers' duties to contribute to the growth of soft skills of learners and values of honesty, piety, discipline, obedience, sensitivity, and kindness must be instilled apply to the learners.

\section{REFERENCES}

David, Ferly. 2009. Pengembangan Soft Skill untuk Mahasiswa. Bandung: UK Maranatha.

Gunawan,Adi W. 2005. Born to be Genius. Jakarta: Gramedia.

Munadi, Yudhi. 2008. Media Pembelajaran, Sebuah Pendekatan Baru.Jakarta: Gaung Persada Press.

Sanjana, Wina. 2008. Perencanaan dan Desain Sistem Pembelajaran. Jakarta: Kencana Prenada Media Grup.

Suprijanto. 2007. Pendidikan Orang Dewasa, dari Teori hingga Aplikasi. Jakarta: Bumi Aksara. 